\title{
Meningkatkan Kesejahteraan Masyarakat Melalui Layanan Informasi Terseleksi Perpustakaan Desa dengan Participatory Rural Appraisal(PRA)
}

\author{
Maretha Indriyanti ${ }^{1, *}$, Muh Ahlis Ahwan ${ }^{2}$ \\ ${ }^{1}$ Universitas Negeri Semarang, Indonesia \\ ${ }^{2}$ Universitas Islam Negeri Walisongo Semarang, Indonesia
}

\author{
Paper type: \\ Research article \\ Article history: \\ Received April 1, 2021 \\ Revised November 3, 2021 \\ Accepted November 4, 2021 \\ Keywords: \\ - Information \\ dissemination \\ - Information literacy \\ - PKK \\ - Participatory Rural \\ Appraisal
}

\begin{abstract}
Purpose. This study aims to show that selected information services (information dissemination) of village libraries can improve the prosperity of residents in the Wonosalam District Demak Regency.

Methodology, the approach used in this study is Participatory Rural Appraisal (PRA), an action of three stages (preparation, implementation, and evaluation). PRA was carried out collaboratively by the village library, sub-district officials, and cadres of PKK (a group of women concerned about family well-being) in a frame of community service activity.

Discussion. This study shows that there is potential for PKK-assisted residents to develop their talents and interests through selected information services from the village library. The PKK assisted residents and librarians carried out this activity to access and find appropriate sources of information from various media and train new entrepreneurship skills. This collaborative activity turned out to grow the residents of Wonosalam District, Demak Regency's skills and create an entrepreneurship view for their prosperity.

Conclusion. the selected information service has made PKK assisted residents aware that the village library can open new information and insights and create user experiences for their lives. It gradually changes the residents' mindset and makes their families and surrounding communities able to be prosperous.
\end{abstract}

\section{Pendahuluan}

Perpustakaan desa merupakan perpustakaan yang diselenggarakan oleh pemerintah tingkat desa atau kelurahan yang memiliki tugas pokok dalam melaksanakan pengembangan perpustakaan di wilayah desa atau kelurahan tersebut serta melaksanakan layanan perpustakaan kepada masyarakat umum tanpa membedakan identitasnya (Standar Nasional Perpustakaan Desa/Kelurahan, 2017). Pemerintah telah mengembangkan model perpustakaan berbasis inklusi sosial yakni penguatan literasi untuk menyejahterakan masyarakat (Asep Saeful Rohman, 2018). Setiap desa atau kelurahan memiliki anggaran pembangunan desa yang dapat dialokasikan untuk pengembangan perpustakaan desa atau kelurahan dengan melengkapi dan meningkatkan kualitas sumber daya yang dimilikinya (Rohman \& Sukaesih, 2018). Perpustakaan desa atau kelurahan sebagai sarana kegiatan dan belajar bagi masyarakat diharapkan dapat berperan aktif dalam mewujudkan keberhasilan berbagai program pemberdayaan masyarakat, antara lain adalah Pemberdayaan Kesejahteraan Keluarga (PKK).

\section{${ }^{*}$ Corresponding author.}

Email addresses: marethaindriyanti@mail.unnes.ac.id (M. Indriyanti), ahlisahwan@walisongo.ac.id (M. A. Ahwan) 
PKK merupakan organisasi yang dibentuk secara khusus untuk memberdayakan perempuan agar mampu mengembangkan diri di lingkungan masyarakat (Wadu et al., 2018). Perempuan adalah motorik bagi keluarga, bahkan menjadi tumpuan untuk keberlangsungan keluarga, sehingga perempuan perlu didukung dengan kemampuan literasi informasi melalui program PKK (Nuryati et al., 2018). Literasi adalah kemampuan individu dalam mengolah informasi dan pengetahuan untuk kecakapan hidup (Badan Pengembangan dan Pembinaan Bahasa, 2021). Literasi erat kaitannya dengan keberadaan perpustakaan yang menyediakan sumber bacaan atau informasi yang dapat dicari, dipilih, digunakan, dan dievaluasi secara efektif dan efisien untuk menciptakan pengetahuan baru (Martin, 2013; Tewell, 2015). Keberadaan perpustakaan desa secara tidak sadar merupakan upaya pemberdayaan masyarakat yang menggambarkan pola-pola pemberdayaan lebih produktif dengan cara membaca bahan pustaka yang ada di perpustakaan lalu menyerap hasilnya untuk dipraktikkan dalam kehidupan bermasyarakat (Maskurotunitsa \& Rohmiyati, 2016). Salah satu pemberdayaan masyarakat yang tertuang dalam 10 program pokok PKK adalah pendidikan dan keterampilan (Peraturan Presiden RI, 2017), kegiatan tersebut merupakan kegiatan yang dilakukan oleh masyarakat, antara lain warga di daerah Kecamatan Wonosalam Kabupaten Demak.

Kecamatan Wonosalam adalah salah satu kecamatan yang berada di Kabupaten Demak Jawa Tengah dengan luas wilayah $\pm 57,88 \mathrm{~km}^{2}$ dan memiliki 21 desa/kelurahan (Demak, 2020). Sebagai daerah agraris, penduduknya sebagian besar hidup dari hasil pertanian, tetapi ada pula buruh tani, pedagang, supir atau kondektur angkutan, pembantu rumah tangga, dan berwirausaha. Beragamnya mata pencaharian tersebut, pihak kecamatan berupaya memberikan perhatian dengan cara mengumpulkan warganya di tiap-tiap kelurahan untuk dibina pada kegiatan PKK agar penduduk desa tidak pasif dalam mengembangkan bakat yang dimiliki. Dalam kegiatan tersebut, kecamatan memberikan dukungan penuh kepada warga khususnya yang tergabung dalam Kelompok Kerja (Pokja) PKK atau disebut "warga binaan PKK" untuk meningkatkan kesejahteraan hidupnya melalui pertemuan-pertemuan rutin yang terjadwal maupun tidak terjadwal. Kegiatan warga binaan PKK di Kecamatan Wonosalam Kabupaten Demak antara lain adalah pendidikan dan keterampilan mulai dari pembuatan kerajinan tangan, hingga pembuatan produk minuman atau makanan. Kegiatan warga binaan PKK ini bertujuan untuk meningkatkan kesejahteraan perokonomian khususnya keluarga dan umumnya masyarakat sekitarnya.

Kebutuhan informasi masyarakat desa sebenarnya dapat terpenuhi dengan adanya peran perpustakaan (Bahaudin \& Wasisto, 2018). Berdasarkan observasi awal, setiap desa atau kelurahan di Kecamatan Wonosalam memiliki perpustakaan atau Taman Baca Masyarakat (TBM). Perpustakaan desa dan TBM tersebut sebagian tergolong bagus, lengkap dan bahkan pernah menjuarai perlombaan, tetapi sebagian hanya sebatas syarat untuk kelengkapan fasilitas layanan desa. Perpustakaan dapat berperan aktif dalam memberikan layanan kepada warga binaan PKK, layanan tersebut adalah diseminasi informasi atau layanan informasi terseleksi. Diseminasi informasi ini penting karena dapat menggerakkan warga binaan PKK untuk memperoleh informasi yang relevan dengan keterampilannya, layanan informasi terseleksi ini juga dapat menumbuhkan gagasan atau ide baru guna mencapai keberhasilan tujuan pembangunan masyarakat. (Rodiah et al., 2018).

Masyarakat desa sebagai pemustaka menjadi barometer keberhasilan suatu kegiatan layanan perpustakaan desa atau kelurahan. Pemustaka yang berada di lingkungan desa memiliki karakteristik yang berbeda, ada pemustaka yang berkunjung ke perpustakaan sekedar mengisi waktu luang dan ada juga yang berkeinginan memanfaatkan layanan perpustakaan sebagai suatu kebutuhan, hal itu bisa terlihat dari sikap pemustaka saat 
memanfaatkan perpustakaan desa. Penna dalam Widuri (2015) menguraikan bahwa karakteristik pemustaka dalam menunjang aktivitas perpustakaan antara lain (a) individual of group yaitu pengguna datang ke perpustakaan sebagai individu atau sebagai suatu kelompok; (b) place of learning yaitu tempat yang biasa digunakan oleh pengguna untuk membaca buku atau belajar; (c) social situation yaitu aspek sosial dari pengguna perpustakaan; (d) leisure or necessity factor yaitu pengguna berkunjung ke perpustakaan untuk sekedar mengisi waktu luang atau karena dia membutuhkan buku atau informasi tertentu; (e) subject of study yaitu bidang yang sedang didalami pengguna, apakah dia sedang menulis mengenai suatu subjek tertentu yang sangat khusus atau lebih luas; (f) level of study yaitu tingkat pendidikan pengguna; (g) motivation yaitu sejauh mana keinginan dan antusiasme pengguna dalam memanfaatkan layanan perpustakaan.

Pemustaka di daerah Kecamatan Wonosalam Kabupaten Demak memiliki karakter yang beragam, ada yang individual of group, ada pula pemustaka yang memiliki karakter social situation, serta ada juga pemustaka yang berkarakter leisure or necessity factor. Keanekaragaman karakteristik pemustaka menjadi tantangan bagi petugas perpustakaan karena tidak mudah meningkatkan kemampuan literasi mereka (Nuryati et al., 2018). Perlu partisipasi aktif masyarakat, yakni petugas perpustakaan, warga, dan pemerintah untuk memanfaatkan layanan informasi terseleksi secara bersama-sama, sehingga seluruh komponen bersinergi dalam membangun kesejahteraan masyarakat di Kecamatan Wonosalam Kabupaten Demak.

Pemerintah memandang perpustakaan desa atau kelurahan merupakan simpul yang sangat strategis dalam mengembangkan dan memberdayakan masyarakat pada tingkat desa atau kelurahan (Ariyani, L.P.S, Wayan M, Nengah B.A, 2017). Berbagai macam informasi yang dimiliki perpustakaan desa serta disediakannya akses internet untuk mencari sumber informasi terkait dengan kegiatan PKK sangat bermanfaat bagi warga Kecamatan Wonosalam Kabupaten Demak, namun kendala yang dihadapi adalah kurangnya kepedulian masyarakat untuk memperoleh informasi aktual yang berkaitan dengan keterampilannya, kurangnya literasi warga dalam memanfaatkan berbagai media untuk mendapatkan informasi di perpustakaan desa, dan belum optimalnya petugas perpustakaan dalam mengembangkan layanan perpustakaan desa melalui diseminasi informasi kepada pemustaka. Oleh karena itu, perpustakaan perlu turut andil dalam kegiatan-kegiatan warga binaan PKK supaya layanan informasi terseleksi dapat mengoptimalkan potensi keterampilan warga di Kecamatan Wonosalam Kabupaten Demak.

Berdasarkan paparan di atas, maka diperlukan suatu tindakan aksi untuk mengetahui bagaimana layanan informasi terseleksi perpustakaan desa dapat meningkatkan kesejahteraan hidup warga di Kecamatan Wonosalam Kabupaten Demak. Kegiatan ini mengkolaborasikan antara unsur perpustakaan desa, warga binaan PKK, dan pemerintah kecamatan melalui pendekatan Participatory Rural Appraisal (PRA) yakni sekumpulan pendekatan dan metode yang mendorong masyarakat pedesaan untuk aktif meningkatkan dan menganalisis pengetahuan mereka mengenai hidup dalam konteks kondisi mereka sendiri agar mereka dapat membuat rencana dan tindakan (Chambers, 1994). Metode PRA merupakan metode yang sangat kredibel untuk program pemberdayaan masyarakat (Hudayana et al., 2019), sehingga kajian ini diharapkan dapat menyajikan sebuah pandangan bahwa layanan informasi terseleksi mampu meningkatkan kesejahteraan hidup suatu masyarakat dan memperkaya khasanah keilmuan dalam bidang perpustakaan maupun bidang lain yang terkait. 


\section{Metode}

Kegiatan ini menggunakan metode Participatory Rural Appraisal (PRA), yakni pendekatan partisipasi aktif warga dalam proses diseminasi informasi yang sedang dilakukan dari tahap awal berupa persiapan hingga akhir berupa evaluasi yang bermuara pada penerimaan manfaat bagi masyarakat (Herdiana et al., 2019). Metode PRA dilakukan melalui kegiatan pengabdian kepada masyarakat yang dilakukan oleh Universitas Negeri Semarang yang menyasar kepada petugas-petugas perpustakaan desa dan warga Kecamatan Wonosalam Kabupaten Demak yang diprioritaskan berkecimpung dalam Kelompok Kerja (Pokja) PKK atau warga binaan PKK.

Kegiatan pengabdian ini memediasi tiga unsur di daerah Kecamatan Wonosalam Kabupaten Demak, yakni: (1) warga binaan PKK; (2) perpustakaan desa; dan (3) pemerintah kecamatan. Peran pemerintah kecamatan dalam kegiatan ini adalah memfasilitasi tempat, sarana-prasarana, dan menentukan waktu pelaksanaan kegiatan, sedangkan peran warga binaan PKK dan perpustakaan desa sebagai peserta dalam program pengabdian ini. Kegiatan ini juga menghadirkan narasumber dari Universitas Islam Negeri Semarang sebagai fasilitator yang memahami kepustakawanan. Kegiatan diseminasi informasi melalui metode PRA ini dilakukan melalui tiga tahapan yang ditunjukkan dalam Tabel 1.

Tabel 1. Kegiatan diseminasi informasi berbasis Participatory Rural Appraisal(PRA)

\begin{tabular}{|c|c|c|c|}
\hline No & Tahapan & Kegiatan & Keterangan \\
\hline 1 & Persiapan & $\begin{array}{l}\text { 1. Mengamati kondisi lokasi dan latar belakang warga Kecamatan } \\
\text { Wonosalam Kabupaten Demak, serta mengidentifikasi minat baca } \\
\text { masyarakat dan faktor kendala dan pendukung apa saja untuk } \\
\text { meningkatkan kegiatan diseminasi informasi. }\end{array}$ & $\begin{array}{l}\text { Semua unsur, yaitu } \\
\text { warga binaan PKK, } \\
\text { perpustakaan desa, } \\
\text { pemerintah } \\
\text { kecamatan } \\
\text { melakukan } \\
\text { Community Action } \\
\text { Plan(CAP), yaitu }\end{array}$ \\
\hline 2 & Pelaksanaan & $\begin{array}{l}\text { 1. Sosialisasi dengan pengarahan bahwa perpustakaan bukanlah hanya } \\
\text { dalam bentuk sebuah gedung/ ruangan dan berisikan buku-buku, } \\
\text { tetapi dapat berbentuk segala macam media. } \\
\text { 2. Pelatihan dengan menelusur sumber-sumber informasi melalui } \\
\text { kelompok-kelompok sesuai bakat dan kegemaran individu serta } \\
\text { mempraktikan keterampilan baru yang diperolehnya. } \\
\text { 3. Pendampingan dengan mengarahkan dan membimbing peserta dalam } \\
\text { mempraktikan hasil penelusuran sesuai bakat dan minat keterampilan. }\end{array}$ & $\begin{array}{l}\text { mempersiapkan } \\
\text { perencanaan, } \\
\text { pendanaan, jadwal, } \\
\text { melakukan aksi, } \\
\text { serta melakukan } \\
\text { monitoring dan } \\
\text { evaluasi } \\
\text { (Hudayana et al., }\end{array}$ \\
\hline 3 & Evaluasi & $\begin{array}{l}\text { Menilai proses dari awal sampai akhir dan melihat dampak atau manfaat } \\
\text { yang dirasakan oleh masyarakat dengan adanya kegiatan diseminasi } \\
\text { informasi. }\end{array}$ & 2019). \\
\hline
\end{tabular}

\section{Pembahasan}

\subsection{Tahap Persiapan}

Pelaksanaan kegiatan diseminasi informasi ini diawali dengan mengamati lokasi dan latar belakang warga di Kecamatan Wonosalam Kabupaten Demak. Kecamatan ini memiliki 21 desa/kelurahan dengan jumlah penduduk sebanyak 78.035 orang pada tahun 2019, terdiri atas 38.631 laki-laki dan 39.404 perempuan. Menurut kelompok umur, sebagian besar penduduk Kecamatan Wonosalam termasuk dalam usia produktif (15-64 tahun) sebanyak 61.853 orang $(79,26 \%)$ dan 19.662 orang $(25,20 \%)$ berusia dibawah 15 tahun dan 4.895 orang $(6,27 \%)$ berusia 65 tahun keatas, sedangkan besarnya angka ketergantungan (dependency ratio) Kecamatan Wonosalam adalah 459,74. Hal ini 
menunjukkan bahwa setiap 1.000 orang berusia produktif menanggung sebanyak 460 orang lebih penduduk usia dibawah 15 tahun dan 65 tahun keatas. Penduduk Kecamatan Wonosalam Kabupaten Demak sebagian besar memiliki mata pencaharian petani sendiri, buruh tani, pengusaha, buruh industri, buruh bangunan, pedagang, angkutan, PNS, pensiunan, dan lainnya. Kepercayaan penduduk di wilayah Kecamatan Wonosalam sebagian besar menganut agama Islam dan masih kental dengan budaya warisan leluhurnya bahwa kegiatan keagamaan rutin dilakukan seperti misalnya acara tahlilan, berziarah ke makam setiap hari kamis sore, dan pengajian-pengajian.

Setiap desa di Kecamatan Wonosalam Kabupaten Demak memiliki perpustakaan desa atau Taman Baca Masyarakat (TBM), namun perpustakaan desa di daerah Kecamatan Wonosalam Kabupaten Demak memiliki beberapa kendala, antara lain (1) petugas perpustakaan desa masih berlatar belakang pendidikan selain ilmu perpustakaan, tetapi dianjurkan untuk memahami kegiatan kepustakawanan, hal tersebut terlihat bahwa petugas perpustakaan kesulitan dalam mengembangkan kegiatan kepustakawanan seperti melakukan inovasi untuk meningkatkan layanan perpustakaan. (2) kurangnya pemanfaatan sumber daya perpustakaan desa, padahal perpustakaan telah memiliki bahan pustaka yang relatif lengkap misalnya buku, majalah, surat kabar, dokumen, kliping dan jurnal kegiatan desa, bahkan perpustakaan desa menyediakan fasilitas internet. Hal ini juga masih kurangnya dukungan pihak-pihak terkait seperti pemerintah setempat dan lembaga pemberdayaan masyarakat sehingga sumberdaya di perpustakaan desa belum dimanfaatkan secara optimal. Sebagian warga juga masih memiliki minat baca rendah karena sebagian besar penduduk desa tidak mengenyam pendidikan yang tinggi sehingga penduduk jarang memanfaatkan perpustakaan desa secara kontinu. (3) Kebanyakan penduduk masih cenderung berpola pikir kuno atau belum up to date karena untuk mendapat ilmu dan informasi itu dianggap tidak penting.

Berpijak pada observasi di atas, maka perlu menyusun program kegiatan untuk mencari solusi dan memunculkan potensi yang dimiliki warga. Kegiatan tersebut adalah layanan informasi terseleksi melalui kegiatan pengabdian kepada masyarakat yang diikuti oleh petugas perpustakaan dan warga binaan PKK. Program tersebut dilakukan dalam tiga tahapan dengan rentang waktu yang berbeda, yaitu tahap pertama memberi sosialisasi tentang pentingnya pengetahuan penelusuran informasi yang dapat diakses dari berbagai media seperti buku atau internet di perpustakaan. Tahap kedua melatih cara mengakses sumber-sumber informasi dengan membuat kelompok-kelompok sesuai bakat dan kegemaran individu supaya lebih terarah dalam menelusur informasi. Tahap ketiga yaitu pendampingan terhadap peserta dalam mempraktikkan hasil penelusuran sehinga peserta tidak mengalami hambatan.

Agar program pengabdian kepada masyarakat dapat terlaksana dengan baik, perlu kolaborasi antar unsur, yaitu petugas perpustakaan desa, perangkat/pemerintah kecamatan, dan warga binaan PKK, dan perlu juga menghadirkan narasumber dari luar sebagai fasilitator yang berkompeten dalam bidang kepustakawanan untuk membimbing supaya kegiatan diseminasi informasi dapat menuai hasil yang optimal.

\subsection{Tahap Pelaksanaan}

Kegiatan pertama dilaksanakan di Kantor Kecamatan Wonosalam Kabupaten Demak dengan peserta perwakilan Pokja II dari masing-masing desa sebanyak 2 orang. Kegiatan ini mensosialisasikan betapa pentingnya pengetahuan terhadap penelusuran sumbersumber informasi perpustakaan desa yang dapat dilakukan melalui berbagai media. Pandangan mereka selama ini mengenai perpustakaan desa hanya berkaitan dengan buku dan sejenisnya, tetapi ternyata ilmu yang berhubungan dengan perpustakaan bentuknya 
sangat luas dan dapat dikembangkan sesuai informasi yang didapatkan. Pada kegiatan pertama ini narasumber mulai mengelompokan warga binaan PKK yang memiliki bakat yang sama supaya dapat menelusur sumber-sumber informasi terseleksi sesuai bakat minat keterampilannya, contohnya bakat memasak, maka kegiatan penelusuran informasi saat itu tentang berbagai macam resep-resep masakan atau hidangan cemilan yang nantinya hasil penelusuran itu dapat langsung dipraktikkan oleh kelompok belajar tersebut. Warga tentu sangat tercerahkan dengan temuan-temuan informasi yang didapatkan melalui penelusuran informasi, sesuai pendapat Daryanto \& Rahardjo (2012) bahwa cara yang baik untuk menunjang keberhasilan belajar adalah membentuk kelompok belajar, anggotanya tidak perlu banyak tetapi cukup beberapa orang saja. Setiap kelompok belajar mempunyai kesamaan pandangan untuk menentukan tujuan penelusuran informasi yang dikehendaki bersama.

Pertemuan kedua disepakati bersama oleh warga binaan PKK untuk dilaksanakan di Desa Doreng, salah satu desa di Kecamatan Wonosalam Kabupaten Demak. Kegiatan kedua dihadiri oleh warga binaan PKK dari desa setempat dan ditambah beberapa perwakilan Pokja II dari desa lainnya. Kegiatan ini memberikan pelatihan cara mengakses informasi di internet melalui audio/suara. Warga semula belum mengetahui bahwa ternyata penelusuran informasi dapat dilakukan dengan berbagai cara seperti menggunakan voice atau icon audio di smartphone dan melalui perangkat lainnya (komputer/laptop) yang disediakan di perpustakaan desa, karena mereka selama ini hanya mengetahui penelusuran informasi dengan teks atau mengetikkan hurus-huruf pada layar browser. Ketika mempraktikkan penelusuran dengan cara audio, banyak yang senang dan terheran dengan kecanggihan teknologi yang setiap harinya padahal dipegang oleh mereka.

Pertemuan selanjutnya yakni kegiatan ketiga yang dilaksanakan di Desa Jogoloyo dan dihadiri beberapa perwakilan warga binaan PKK dari Pokja II dan ibu sekretaris desa (Carik). Kegiatan ini dilaksanakan dengan mendampingi peserta dalam mempraktikkan informasi yang baru diperolehnya. Peserta dibimbing oleh narasumber tentang bagaimana memilih dan memilah informasi yang kredibel dan relevan dengan kebutuhan wirausaha mereka, misalnya mengarahkan kelompok belajar yang kegemarannya atau bakatnya menjahit dan menyulam, maka narasumber mengajarkan menelusur dan menentukan informasi yang berkaitan dengan cara-cara menjahit atau menyulam yang benar dan kreasi apa saja yang dapat dihasilkan dari menjahit atau menyulam tersebut. Kemudian narasumber juga mengajarkan cara menelusur dan memilih resep dalam membuat jamu herbal, peserta memulai dengan memilih satu resep jamu dari beberapa sumber, penentuan resep tersebut sudah melalui diskusi dengan mencari resep yang lebih mudah dimengerti atau bahasanya lebih dipahami dan bahan-bahan praktiknya mudah disediakan, kamudian mereka mempraktikkan.

Kegiatan keempat masih mendampingi bagaimana praktik menelusur informasi dengan satu tema tetapi hasil yang diperoleh beragam, sehingga peserta dapat memilih dan menentukan informasi mana yang tepat untuk digunakan sebagai acuan. Kegiatan ini dilaksanakan di Balai Desa Kerangkulon, dan ternyata peserta antusias mempraktikkan bagaimana cara mengakses informasi yang bermanfaat kemudian menyeleksi hasil penelusuran yang dapat dipraktikan secara terus menerus.

Beberapa kegiatan yang telah dilaksanakan secara bertahap di desa yang berbeda memperlihatkan bahwa warga semangat dan antusias menerima ilmu yang dianggap baru, sehingga hal ini menjadi motivasi bagi warga untuk mulai beranjak dalam menelusur dan menyeleksi informasi yang dibutuhkan guna mengembangkan bakat dan minat sesuai keterampilannya. Kegiatan pengabdian ini juga dilaksanakan sebagai ajakan warga untuk tidak gagap teknologi dan mau memanfaatkan fasilitas layanan perpustakaan desa melalui layanan informasi terseleksi. Dengan cara ini, warga di Kecamatan 
Wonosalam Kabupaten Demak diharapkan sadar akan kebutuhan informasi dan mampu mengembangkan keterampilannya.

Seluruh peserta dari berbagai unsur turut andil dalam melaksanakan kegiatan dengan berkolaborasi. Petugas perpustakaan di masing-masing kelurahan memahami bagaimana cara mengakses informasi melalui internet, dan membantu dalam kegiatan kelompok belajar masing-masing warga desanya. Pihak perangkat kecamatan sebagai penyedia fasilitas juga memberikan respon dan dukungan kepada setiap peserta, seperti memberi fasilitas jaringan internet untuk mengakses informasi dan menyediakan narasumber untuk mengarahkan. Warga binaaan PKK juga semangat dalam menerima arahan, mempraktikkan secara berkelompok, dan berkenan dibimbing oleh narasumber, sehingga kegiatan pengabdian ini dapat memacu tumbuhnya minat masyarakat memanfaatkan perpustakaan desa dengan layanan informasi terseleksi.

Kegiatan ini tentu dapat menggugah warga binaan PKK bahwa melakukan penelusuran informasi yang berkaitan dengan bakat dan minat yang dimilikinya secara bersama-sama atau berkelompok itu asyik, karena akan saling memotivasi satu sama lain, saling berdiskusi, bertukar hasil pemikiran, dan saling menyepakati informasi mana yang akan dipraktikkan saat itu maupun di kemudian hari, sehingga manfaat kegiatan layanan informasi terseleksi ini diharapkan menjadi rutinitas dalam mengembangkan kreativitas melalui layanan informasi terseleksi perpustakaan desa.

\subsection{Tahap Evaluasi}

Secara garis besar dari kegiatan di beberapa desa di Kecamatan Wonosalam Kabupaten Demak menunjukkan bahwa warga antusias memanfaatkan layanan informasi terseleksi. Kegiatan ini menjadi wawasan baru bagi warga untuk menemukan informasi-informasi yang berguna bagi perkembangan kegiatan wirausaha. Selain diseminasi, literasi informasi juga perlu dilatih kepada masyarakat desa supaya literat dan mengetahui banyak hal yang sebenarnya dapat dipetik dari layanan informasi terseleksi perpustakaan desa. Seperti dalam Diagram 1, bahwa dampak dari tujuan pelaksanaan kegiatan dapat berpedoman pada ilmu teknologi.

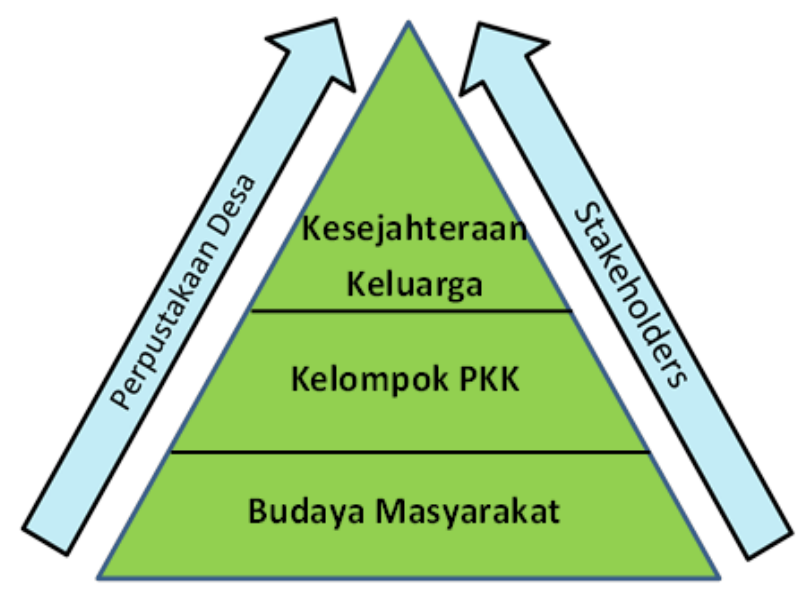

Diagram 1. Gambaran Transfer Iptek pada Warga Binaan

Kegiatan praktik secara langsung tersebut tidak sia-sia karena beberapa warga binaan PKK di kemudian hari menyampaikan bahwa ilmu yang didapat sering dipraktikkan secara mandiri di rumahnya dan bahkan telah menjadi usaha sehari-hari untuk mendapatkan 
penghasilan tambahan bahkan utama. Hal ini tentu merangsang warga binaan PKK bahwa dengan mempraktikkan hasil yang diperoleh dari penelusuran informasi dapat berguna untuk kegiatan wirausaha.

Kegiatan layanan informasi terseleksi melalui PRA terbukti dapat merubah cara pandang dan pola pikir masyarakat mengenai perpustakaan desa. Warga di Kecamatan Wonosalam Kabupaten Demak khususnya warga binaan PKK selama ini beranggapan bahwa kesan perpustakaan hanya sebatas tempat terbatas pada buku-buku saja, namun sekarang warga binaan telah memahami bahwa penelusuran informasi yang dilakukan melalui perpustakaan desa mampu mengubah masyarakat menjadi lebih adaptif terhadap hal baru dan mampu meningkatkan pendapatan untuk mensejahterakan hidupnya.

Manfaat yang dapat diperoleh dari kegiatan ini antara lain (1) melatih petugas perpustakaan untuk lebih berperan-serta dalam memberikan dan mengembangkan layanan-layanan perpustakaan desa melalui kegiatan-kegiatan warga; (2) memberi motivasi warga bahwa kebaruan informasi terus berubah dan dapat diakses secara mudah di perpustakaan desa; (3) hasil dari informasi yang ditemukan dapat diaplikasikan dalam berwirausaha dan menjadi penghasilan lebih bagi warga. Harapan penduduk Kecamatan Wonosalam Kabupaten Demak adalah layanan informasi terseleksi perpustakaan desa dapat dilakukan secara berkesinambungan supaya dampak bagi warga dapat terus dirasakan.

\section{Simpulan}

Kegiatan PRA yang dilaksanakan oleh petugas perpustakaan desa, perangkat kecamatan, dan warga binaan PKK di Kecamatan Wonosalam Kabupaten Demak telah memberikan pencerahan bahwa perpustakaan dapat berperan dalam meningkatkan kesejahteraan warga melalui layanan informasi terseleksi. Hasil penelusuran informasi yang diperoleh menumbuhkan semangat warga binaan PKK untuk mengembangkan inovasi baru sesuai bakat dan minat yang dimiliki. Kegiatan layanan penelusuran informasi terseleksi ini membuktikan bahwa petugas perpustakaan dapat berperan penting dalam menyebarkan informasi terseleksi melalui kegiatan-kegiatan warga. Dengan dirasakannya manfaat dan terbukanya pikiran masyarakat akan hadirnya perpustakaan desa tentu lambat laun dapat merubah pola pikir masyarakat bahwa perpustakaan desa ternyata mampu meningkatkan kesejahteraan kehidupan keluarga dan masyarakat sekitarnya.

Daftar Pustaka

Ariyani, L.P.S, Wayan M, Nengah B.A, D. M. . (2017). Pemberdayaan Pemuda dalam Pengembangan Perpustakaan Desa Untuk Meningkatkan Kemampuan Literasi Masyarakat. Seminar Nasional Pengabdian Masyarakat 2017, 449-455.

Asep Saeful Rohman, W. E. D. E. L. (2018). Transformasi Perpustakaan Desa Untuk Peningkatan Kualitas Hidup Masyarakat Pedesaan Di Kabupaten Majalengka. Jurnal Pengabdian Masyarakat Universitas Padjajaran, 2(12), 1-5. http://jurnal.unpad.ac.id/pkm/article/view/20269/9901

Badan Pengembangan dan Pembinaan Bahasa. (2021). Kamus Besar Bahasa Indonesia Daring. Kementerian Pendidikan, Kebudayaan, Riset, dan Teknologi Republik Indonesia. https://kbbi.kemdikbud.go.id/entri/literasi

Bahaudin, M. S., \& Wasisto, J. (2018). PERAN PERPUSTAKAAN DESA DALAM PEMBERDAYAAN MASYARAKAT (Studi Kualitatif Perpustakaan "Pelita" Desa 
Muntang). Jurnal IImu Perpustakaan, 72), 61-70.

https://ejournal3.undip.ac.id/index.php/jip/article/view/22895

Chambers, R. (1994). Participatory rural appraisal (PRA): Analysis of experience. World

Development, 22(9), 1253-1268. https://doi.org/https://doi.org/10.1016/0305750X(94)90003-5

Daryanto, \& Rahardjo, M. (2012). Model Pembelajaran Inovatif. Gava Media.

Demak, B. K. (2020). Kecamatan Wonosalam Dalam Angka Wonosalam Subdistrict in Figures 2020.

Herdiana, D., Heriyana, R., \& Suhaerawan, R. (2019). Pemberdayaan Masyarakat Melalui Gerakan Literasi Perdesaan di Desa Cimanggu Kabupaten Bandung Barat. Jurnal Pengabdian Pada Masyarakat, 4(4), 431-442. https://doi.org/10.30653/002.201944.208

Hudayana, B., Kutanegara, P. M., Setiadi, S., Indiyanto, A., Fauzanafi, Z., Nugraheni, M. D. F., Sushartami, W., \& Yusuf, M. (2019). Participatory Rural Appraisal (PRA) untuk Pengembangan Desa Wisata di Pedukuhan Pucung, Desa Wukirsari, Bantul. Bakti Budaya, 2(2), 3. https://doi.org/10.22146/bb.50890

Standar Nasional Perpustakaan Desa/Kelurahan, Pub. L. No. Nomor 6 Tahun 2017 (2017). https://www.perpusnas.go.id/lawdetail.php?lang=id\&id=170921083750rcytXZpfWx

Martin, J. (2013). Refreshing information literacy: Learning from recent British information literacy models. Communications in Information Literacy, 72), 114 127. https://doi.org/10.15760/comminfolit.2013.7.2.142

Maskurotunitsa, R. S., \& Rohmiyati, Y. (2016). Peran Perpustakaan Desa "Mutiara" Dalam Pemberdayaan Masyarakat Desa Kalisidi Kecamatan Ungaran Barat Kabupaten Semarang. Jurnal IImu Perpustakaan, 5(4), 81-90. https://ejournal3.undip.ac.id/index.php/jip/article/view/15335/14830

Nuryati, N., Sutjiredjeki, E., \& Lasambouw, C. M. (2018). Peningkatan Literasi Informasi Untuk Mendukung Pemberdayaan Perempuan Di Desa Sariwangi Kecamatan Parongpong Kabupaten Bandung Barat. Jurnal Difusi, 1(1). https://jurnal.polban.ac.id/ojs-3.1.2/difusi/article/view/1017/833

Peraturan Presiden Republik Indonesia Nomor 99 Tahun 2017 tentang Gerakan Pemberdayaan dan Kesejahteraan Keluarga, Pub. L. No. 99, 1 (2017).

Rodiah, S., Budiono, A., \& Komariah, N. (2018). PENGUATAN PERAN PERPUSTAKAAN DESA DALAM DISEMINASI INFORMASI KESEHATAN LINGKUNGAN. Dharmakarya: Jurnal Aplikasi Ipteks untuk Masyarakat, 73), 197-202. https://jurnal.unpad.ac.id/dharmakarya/article/view/19350/10341

Rohman, A. S., \& Sukaesih, S. (2018). Transformasi Perpustakaan Desa Untuk Pemberdayaan Masyarakat: Studi Kasus Di Desa Margamukti - Pangalengan Bandung. Jurnal Perpustakaan Pertanian, 26(2), 47. https://doi.org/10.21082/jpp.v26n2.2017.p47-54

Tewell, E. (2015). A DECADE OF CRITICAL INFORMATION LITERACY: A review of the literature. Communications in Information Literacy, 9(1), 24-43. https://files.eric.ed.gov/fulltext/EJ1089135.pdf

Wadu, L. B., Ladamay, I., \& Dadi, M. Y. (2018). Faktor Pendukung dan Penghambat Pembinaan Kesejahteraan Keluarga (PKK) Dalam Meningkatkan Keterampilan Warga Negara Melalui Program Pokok PKK. Jurnal Inspirasi Pendidikan, 8(1), 62-71. https://doi.org/10.21067/jip.v8i1.2244

Widuri, N. R. (2015). Pena Pustakawan: Bunga Rampai Publikasi Perpustakaan - Google Cendekia. Yrama Widya. https://scholar.google.co.id/scholar?hl=id\&as_sdt=0,5\&cluster=13477080319311144 404 